\title{
Who Studies Abroad at US Community Colleges?
}

\author{
Melissa Whatley, \\ ${ }^{a}$ Institute of Higher Education, University of Georgia, United States \\ *Corresponding author: Email: melwhat@uga.edu \\ Address: Institute of Higher Education, University of Georgia, Athens, Georgia, United States
}

\section{Introduction}

In the United States, public two-year institutions, or community colleges, enroll approximately 40 percent of all postsecondary students (AACC 2018; NCES 2018). These institutions originated with the purpose of serving local communities (Vaughan 1995) and often offer multiple pathways to student success, including continuing adult education, short-term certificate programs, and Associate's degrees (González Canché 2018). Community colleges frequently serve as a pointof-entry to higher education for underserved student groups, such as first-generation, ethnic minority, lowincome, and academically under-prepared students (Brand, Pfeffer, and Goldrick-Rab 2014). Given this demographic, it is not surprising that community college students participate in education abroad opportunities at disproportionately low rates given both the cost and social norms surrounding who studies abroad. In 2015-16, these students represented only around 1.7 percent of US students participating in study abroad programs (IIE 2017). During this same academic year, approximately 30 percent of public, two-year institutions reported that their students had the opportunity to participate in education abroad experiences. This percentage contrasts sharply with public four-year institutions, of which 80 percent reported that study abroad was an opportunity available to their students (author's calculations using IPEDS). This article discusses in-progress research that seeks to identify characteristics of community college students who study abroad.

\section{Community College Students' Capital Resources}

Social stratification theory suggests that individuals are able to access different amounts and types of capital resources due to uneven social structures. In addition to economic capital, Bourdieu (1986) suggests that individuals also depend on both cultural and social capitals for social advancement. Cultural capital is defined as informal interpersonal skills, habits, manners, linguistic competencies, and lifestyle preferences of a given group (Berger 2000), while social capital is comprised of social relationships and the resources available through them (Portes 1998). Prior research has demonstrated that students' capital resources inform their decisions surrounding study abroad. This research, involving students enrolled at four-year institutions, suggests that resources such as financial aid (economic), participation in extracurricular activities (cultural), and peer support (social) are significant predictors of (intent to) study abroad (Salisbury, Umbach, Paulsen, and Pascarella 2009; Simon and Ainsworth 2012; Whatley 2018). The study presented here expands this research to the community college sector and includes capital resource-related characteristics that may be especially important to community college students, such as whether a student completed high school by taking a general education development (GED) exam rather than course completion and whether a student is enrolled part-time rather than full-time.

\section{Method}

The data that inform this study were provided by an urban community college located in the US Southeast. This community college offers a range of degree opportunities to students, including certificates and technical degrees, as well as a wide variety of 
Associate's degrees and transfer options. Students who intend to transfer to the four-year sector are able to take advantage of articulation agreements between this institution and the state's primary four-year institution. Study abroad opportunities are offered to students during two of the three terms that comprise the academic year and are primarily short-term programs. Students have the opportunity to travel to a variety of countries and programs are not concentrated in a single region of the world.

Data represent enrollments starting in the 2009-10 academic year through 2016-17 (95,265 observations representing 48,352 students over time). Students who were enrolled for multiple terms are represented multiple times. While some individual student information, such as race/ethnicity, did not change over time, other characteristics, such as need-based aid eligibility or academic achievement (grade point average, GPA) did. An event history analysis allowed for the incorporation of this temporal variation into statistical models that predicted study abroad participation (Box-Steffensmeier and Jones 2004). This analytic feature is important, as many variables that have been shown in prior research to predict study abroad participation (e.g., academic achievement) do not remain the same over time. Restricting such variables to be time-constant obscures their timevarying effects and has the potential to lead to biased conclusions (DesJardins 2003). Event history analysis was developed with this potential source of bias in mind to model the relationship between time-varying predictors and the occurrence of an event (in this case, study abroad participation) (Box-Steffensmeier and Jones 2004). These statistical models estimate the hazard rate of an event occurring over time by observing individuals as they pass from one state (e.g., a non-participant in study abroad) to another (e.g., a study abroad participant) (DesJardins 2003).

\section{Preliminary Findings}

Preliminary findings suggest that among students' temporally stable characteristics, race/ethnicity, gender, and residency status were significant predictors of study abroad participation. More specifically, while Asians, Blacks, Hispanics, Whites, and students representing multiple ethnicities were equally as likely to study abroad, students belonging to an "Other" race/ethnicity group were approximately 200 percent more likely to study abroad. In contrast, male students experienced a 40 percent reduction in the likelihood of study abroad participation compared to female students. Students who were classified as in-state residents were approximately 260 percent more likely to study abroad. Students who took the GED exam to complete high school were equally as likely to study abroad as those who completed high school through traditional means.

Turning to characteristics that varied over time, age was associated with a decreased likelihood of study abroad participation, although the decrease associated with an additional year in age was small (0.5 percent). Students who were eligible for need-based financial aid also experienced a decreased likelihood of study abroad participation although, again, the decrease was small (3 percent). In contrast, a GPA increase of one point corresponded to a larger increase in study abroad likelihood (8.6 percent). Compared to students not seeking a degree, students with a specific degree goal were generally more likely to study abroad. Students studying Fine Arts/Humanities, Business, and Social Sciences experienced the highest increases in study abroad likelihood.

\section{Implications}

This investigation's results indicated that study abroad patterns among students attending this particular community college are not entirely dissimilar to those of four-year students examined in previous research. For example, male students were significantly less likely to study abroad compared to females, and the higher a student's GPA, the more likely he/she was to participate. On the other hand, results concerning race/ethnicity are promising in that only one group, students belonging to the "Other" category, were significantly different from White students, and these students were more, not less, likely to study abroad. This pattern differs from results from the four-year 
sector, where underrepresented racial minorities are less likely to (intend to) study abroad (e.g., Salisbury, Paulsen, and Pascarella 2011; Simon and Ainsworth 2012). Although these results are limited to a single institution, they support the idea that community colleges such as this one represents a place where underrepresented racial minorities can access education abroad opportunities. This possibility is especially evidenced by the fact that at this particular institution, students belonging to underrepresented racial minority groups were just as likely to study abroad as White students. One possible explanation for this finding is that the education abroad administrative structures of community colleges are more amenable to these students, who are often navigating unfamiliar higher education institutional bureaucracy (Simon and Ainsworth 2012).

\section{References}

AACC (American Association of Community Colleges). 2018. 2018 Fact Sheet. Washington, DC: AACC. https://www.aacc.nche.edu/wpcontent/uploads/2018/04/2018-Fast-Facts.pdf

Berger, Joseph B. 2000. "Optimizing Capital, Social Reproduction, and Undergraduate Persistence." In Reworking the Student Departure Puzzle, edited by John M. Braxton, 95-124. Nashville, TN: Vanderbilt University Press.

Bourdieu, Pierre. 1986. "The Forms of Capital." In Handbook of Theory and Research for the Sociology of Education, edited by John G. Richardson, 46-58. New York: NY: Greenwood.

Box-Steffensmeier, Janet M., and Bradford S. Jones. 2004. Event History Modeling: A Guide for Social Scientists. New York, NY: Cambridge University Press.

Brand, Jennie E., Fabian T. Pfeffer, and Sara GoldrickRab. 2014. "The Community College Effect Revisited: The Importance of Attending to Heterogeneity and Complex Counterfactuals." Sociological Science 1: 448-465.

DesJardins, Stephen L. 2003. "Event History Methods: Conceptual Issues and an Application to Student
Departure from College. In Higher Education: Handbook of Theory and Research, Vol. XVIII, edited by John C. Smart, 421-472. The Netherlands: Kluwer Academic Publishers.

González Canché, Manuel S. 2018. "Reassessing the Two-year Sector's Role in the Amelioration of a Persistent Socioeconomic Gap: A Proposed Framework for the Study of Community College Effects in the Big and Geocoded Data and Quasiexperimental Era." In Higher Education: Handbook of Theory and Research, edited by Michael B. Paulsen, 175-238. Berlin: Springer.

IIE (Institute of International Education). 2017. Open Doors Report on International Educational Exchange. New York: IIE. https://www.iie.org/opendoors

Portes, Alejandro. 1998. "Social Capital: Its Origins and Applications in Contemporary Sociology." Annual Review of Sociology 24: 1-24.

NCES (National Center for Education Statistics). Digest of Education Statistics. Washington, DC: NCES. https://nces.ed.gov/programs/digest/

Salisbury, Mark H., Michael B. Paulsen, and Ernest T. Pascarella. 2011. "Why Do All the Study Abroad Students Look Alike? Applying an Integrated Student Choice Model to Explore Differences in the Factors that Influence White and Minority Students' Intent to Study Abroad." Research in Higher Education 52(2): 123-150.

Salisbury, Mark H., Paul. D. Umbach, Michael B. Paulsen, and Ernest T. Pascarella. 2009. "Going Global: Understanding the Choice Process of the Intent to Study Abroad." Research in Higher Education 50(2): 119-143.

Simon, Jennifer, and James W. Ainsworth. 2012. "Race and Socioeconomic Status Differences in Study Abroad Participation: The Role of Habitus, Social Networks, and Cultural Capital. ISRN Education, 2012.

Vaughan, George B. 1995. The Community College Story: A Tale of American Innovation. Washington, DC: The American Association of Community Colleges. 
Whatley, Melissa. 2018. "Toward an Understanding of Peer Influence on Undergraduate Study Abroad Participation: A Pilot Study." Frontiers: The
Interdisciplinary Journal of Study Abroad 30(3): 51-71. 